\title{
Amyotrophic lateral sclerosis, Parkinson's disease, and the amyotrophic lateral sclerosis-Parkinsonism- dementia complex on Guam: a review and summary of attempts to demonstrate infection as the aetiology
}

\author{
CLARENCE J. GIBBS JR AND D. CARLETON GAJDUSEK
}

From the National Institutes of Health, Bethesda, Maryland, USA

In a series of lectures delivered in 1874, Charcot described a new syndrome which he termed amyotrophic lateral sclerosis (ALS). At that time he presented the essential pathological and classical characteristics of the disease which, although later modified and refined by himself and subsequent workers, have remained remarkedly classical for ALS during the almost 100 years since they were published. Recently, Goldblatt (1968) has extensively reviewed the literature on motor neurone disease. Most investigators now recognize three forms of ALS: (1) the sporadic or classic, (2) the familial and presumably hereditary, and (3) the Mariana Islands form or the western Pacific islands form which is the major cause of death among the Chamorro Indians, an indigenous population on the island of Guam (Table I). Indeed, the highest incidence of ALS in the world occurs in the Chamorro population coincident with an unusual form of dementia with Parkinsonian features and upper motor neurone changes referred to as the Parkinsonism-dementia complex, which may be a classical variant of the Guam type (Brody and Chen, 1968). It is of interest that this rather isolated population in the Pacific Ocean manifests the presenile dementia of Parkinsonism while the best known of the world's presenile dementias, ie, Alzheimer's disease, Pick's disease, and Creutzfeldt-Jakob disease, have not been clinically recognized as occurring. We have recently had a case of 'Parkinsonism-dementia' which histologically was diagnosed by Hirano as a possible case of Creutzfeldt-Jakob disease with spongiform changes. This patient was a Filipino not born on Guam. The Parkinsonism-dementia complex, although more recently characterized and less well known than ALS, actually accounts for an equal number of adult deaths among the Chamorro population (Brody and Chen, 1968).

It is now well documented that ALS occurs in all countries for which mortality statistics can be ob-

\begin{tabular}{|c|c|c|c|}
\hline \multirow[t]{2}{*}{ Feature } & \multicolumn{3}{|l|}{ Type } \\
\hline & Sporadic & Familial & Guamanian \\
\hline $\begin{array}{l}\text { Age onset (mean) } \\
\text { Mean range } \\
\text { Sex ratio }(\mathbf{M}: \mathbf{F}) \\
\text { Duration (mean) }\end{array}$ & $\begin{array}{l}52-60 \\
(25-75) \\
1 \cdot 6: 1 \\
3-4(1-8)\end{array}$ & $\begin{array}{l}(47) \\
(25-65) \\
1: 1 \\
3(1-10)\end{array}$ & $\begin{array}{l}(46) \\
(20-70) \\
2 \cdot 5: 1 \\
3-5(1-10)\end{array}$ \\
\hline \multicolumn{4}{|l|}{$\begin{array}{l}\text { Clinical features } \\
\text { Primary symptoms }\end{array}$} \\
\hline $\begin{array}{l}\text { Lower extremities } \\
\text { Spasticity }\end{array}$ & $\begin{array}{l}20-25 \% \\
\text { Rare }\end{array}$ & $\begin{array}{l}40-50 \% \\
\text { Rare }\end{array}$ & $\begin{array}{l}20-25 \% \\
15 \%\end{array}$ \\
\hline \multicolumn{4}{|c|}{$\begin{array}{ll}\text { Extrapyramidal } & \text { Rare } \\
\text { signs } & \end{array}$} \\
\hline $\begin{array}{l}\text { signs } \\
\text { Dementia } \\
\text { Sensory changes }\end{array}$ & $\begin{array}{l}\text { Rare } \\
\text { Rare } \\
\text { Not described }\end{array}$ & $\begin{array}{l}\text { Occasional } \\
\text { Occasional } \\
\text { Not described }\end{array}$ & $\begin{array}{l}\text { Rare } \\
\text { Infrequent } \\
\text { Not described }\end{array}$ \\
\hline $\begin{array}{l}\text { Collagen changes in } \\
\text { skin }\end{array}$ & & & \\
\hline \multicolumn{4}{|l|}{$\begin{array}{l}\text { Neuropathological } \\
\text { lesions }\end{array}$} \\
\hline $\begin{array}{l}\text { Demyelination } \\
\text { posterior column } \\
\text { Changes in column }\end{array}$ & Rare & $50 \%$ & Rare \\
\hline $\begin{array}{l}\text { of Clarke } \\
\text { Neurofibrillary } \\
\text { changes before }\end{array}$ & Rare & $50 \%$ & Rare \\
\hline $\begin{array}{l}\text { age } 60 \\
\text { Granulovacuolar }\end{array}$ & Rare & Rare & Common \\
\hline $\begin{array}{l}\text { bodies } \\
\text { Anterior-horn cell }\end{array}$ & Rare & Rare & Occasional \\
\hline inclusion bodies & Not described & Occasional & Not described \\
\hline
\end{tabular}

Table I Clinical and pathological features of three types of $A L S^{1}$

${ }^{1}$ Modified from Kurland, L. T. (1968): Classification of amyotrophic lateral sclerosis. Motor Neuron Diseases, Grune \& Stratton, New York and London, Chapter 4, 28-50.

tained, and in the well developed countries of western Europe and North America as well as in Australia, New Zealand, and Japan, it accounts for about 1 out of every 1000 adult deaths (Kurland, Choi, and Sayre, 1968). Death rates per 100000 vary little throughout the world ranging from 0.05 to $1 \cdot 0$. This means that approximately 1500 people die from ALS per year in the United States, and in a review of data from various countries collected during the past 30 years Brody and his coworkers have found no appreciable change in this rate of 
amyotrophic lateral sclerosis. These same investigators further point out that for all dea:hs over the age of 20 approximately 1 per thousand is from ALS suggesting that the disease is not rare. Indeed, the deaths per year from ALS are about the same as for multiple sclerosis, a far better known disease entity.

Kurland et al (1968) have reported that in the United States there is no appreciable selectivity by region, by metropolitan or non-metropolitan countries, by marital status, or by native versus foreign born. This is in contrast to the foci that occur on Guam and in Japan (Yase, Matsumoto, Yoskinasu, Handa, and Kumamoto, 1968) and there are reports of a slight increase in the rate of ALS among Japanese in the United States based on small numbers and a suggestion of an elevated rate of ALS cases occurring among Filipinos in Hawaii according to Matsumoto and his colleagues as quoted by Brody (1971). Although the reported rate is higher in whites than in non-whites $(1 \cdot 7: 1)$ it is uncertain whether this reflects a true difference in incidence or is related to the availability and utilization of diagnostic services. Brody (1971) has reported that in his studies the mean age of onset in most hospital series is 52 but considers those series to be biased since younger patients are more likely to seek medical attention in referral centres. According to national mortality figures the median age at death is 62 years of age for both males and females.

Clinically ALS presents as a widespread, asymmetrical, steadily progressive muscular weakness with atrophy and fasciculations. Muscular atrophy is the characteristic feature of the syndrome. Initially patients may present with muscular atrophy only, and not until late in the disease does evidence of lateral sclerosis, such as hyperreflexia and Babinski signs, become apparent. Although objective sensory impairment is not generally a part of the clinical picture, cramping muscular pains constitute a frequent complaint (Mulder and Espinosa, 1968).

Classically, histopathological lesions consist of degeneration and loss of neurones in the anterior horns of the spinal cord, in the motor nuclei of the brain stem, and in the Betz cells of the cortex. The neuronal loss is associated with an astrocytic gliosis. Atrophy of muscles and demyelination of the anterior roots and anterolateral columns of the spinal cord, especially the pyramidal tracts, are characteristic features. One may often observe large numbers of macrophages which contain copious amounts of sudanophilic lipid granules. In their description of the histopathological findings in patients with familial ALS Engel, Kurland, and Klatzo (1959) reported severe degeneration of the lower and upper motor neurones, demyelination of the middle root zones of the posterior columns in the spinal cord and bilateral demyelination of the spinocerebellar tract. In one patient they observed two unusual findings: (1) ballooned anterior horn cells which, they suggested, were due to accumulation of hyalin-like material within the cytoplasm of the affected neurons; and (2) accumulation of amorphous material between the Purkinje cell layer and the granular layer of the cerebellum as well as in the region of the culmen.

\section{Amyotrophic Lateral Sclerosis-Parkinsonism Dementia Complex}

The significant concentration of ALS and the related Parkinsonism-dementia (PD) among the Chamorro people on Guam has provided the opportunity to study these syndromes extensively in a stable population since the early 1950s (Brody and Chen, 1968; Brody, Hirano, and Scott, 1971; Elizan, Hirano, Abrams, Need, Van Nuis, and Kurland, 1966). Approximately 1 in 10 Chamorro deaths over the age of 25 is due to ALS and another 1 in 10 is from PD (Brody, 1971). On Guam ALS occurs at a rate more than 50 times higher than in the United States. In this population there is an apparently high rate of conjugal cases and consistently high and low rates of disease in district areas. Patients with ALS on Guam have depressed CNS dopamine metabolism, and a large number of Guamanians have died with subcortical neurofibrillary degeneration without signs of ALS or PD (Brody, 1971).

Native Guamanians are part of the Chamorro linguistic group. Blood group studies suggest that these people are very probably Indo-Malaysian in origin. Currently the indigenous population on Guam are a mixture of Chamorro, Filipino, Spanish, and Mexican. In 1960 the population on Guam was 67 044: 34762 Chamorros, 8580 Filipinos, 20724 Caucasians, and 3000 Carolinians. In 1970 the Chamorro population was $\mathbf{4 0} 000$.

Since 1956, first Kurland and his coworkers and subsequently Brody and his coworkers have been conducting extensive clinical and epidemiological studies of ALS-PD on Guam. Investigations on a less intensified basis had begun at the end of World War II in 1946. In recent years case ascertainment has approached $100 \%$ based primarily on the NINDS facility and the free medical service provided by the Guam Government to patients diagnosed as having ALS or Parkinsonism-dementia. Necropsy rates have exceeded $80 \%$ for all ALS-PD patients dying within the past 10 years (Brody, 1971).

During the past 27 years, 492 cases of ALS and PD have been confirmed. Of this number ALS was diagnosed in three Guamanians who had one grand- 
parent who was not Chamorro, in eight Guamanians with one parent who was not Chamorro, and in four non-Chamorro Filipinos. Parkinsonism-dementia appeared in three Guamanians in whom one parent was not Chamorro. Clinical Parkinsonism has appeared in two Filipinos and in one person who was only one-fourth Chamorro (Brody, 1971).

On Guam $10 \%$ of ALS deaths occur before the age of 40 in both males and females. The mean age of death due to ALS in women is 52.1 while in men it is 50.3 years. In contrast, there have been few cases of PD before the age of 45 with a stable rate of occurrence in women starting around age 50 while in men a significant increase was observed between the ages of 60 and 64.

The ratio of men to women for ALS has been $2 \cdot 5: 1$ while for PD the ratio has been $3.4: 1$ with wide variation in these values among various age groups.

In their series of 321 ALS patients, Brody et al (1971) report that 311 had only motor neurone disease while in 10 some features of dementia and extrapyramidal disease were noted. Signs of upper and lower motor neurone lesions of pseudobulbar, bulbar, and spinal areas were observed at various stages during the course of illness. No weakness of intraocular muscles or of urinary and bowel sphincters was noted and sensory defects were absent in all cases. The age of onset ranged from 20 to 72 and the mean duration of disease once clinical signs had developed was $4 \cdot 1$ years and $4 \cdot 3$ years for men and women, respectively.

Neuropathological lesions were classic for ALS and consisted of moderate to severe degeneration of the upper motor neurone tracts, the somatic motor nuclei, degeneration of neurones in the motor cortex, and in the spinal cord and brain stem.

In the same population the Parkinsonismdementia syndrome accounts for an equal number of adult deaths (Brody and Chen, 1968). The disease has an insidious onset affecting individuals in the fourth to fifth decade of life with Parkinsonian signs accompanied by progressive dementia (Hirano, Kurland, Krooth, and Lessell, 1961a). Akinesia, tremors, flexed posture, and shuffling gait are major signs, and although familial aggregations have been noted no genetic pattern has been elicited to date (Kurland et al, 1968).

Gross pathological lesions have consisted of cerebral atrophy, dilatation of the ventricular system, and depigmentation and atrophy of the substantia nigra (Hirano, Malamud, and Kurland, 1961b). Histopathologically the disease has been characterized by abundant neurofibrillary tangles in the cerebral cortex, basal ganglia, and brain stem (Hirano and Zimmerman, 1962; Hirano, 1966). The tangles themselves are indistinguishable from those seen in Alzheimer's disease and frequently show a flame-like shape in the cerebral cortex while a globose shape is seen in the brain stem.

It is of considerable interest that in their review of 29 Guamanian adults who died of causes other than ALS or PD, Hirano found that in five of these individuals he encountered neurofibrillary changes in the same pattern which he described for the classical PD cases and the ALS cases of Guam. In 12 cases, no neurofibrillary changes were observed. The 12 remaining brains had neurofibrillary tangles only to the extent that is sometimes encountered among non-Chamorro, apparently non-neurological cases (Hirano, Malamud, Elizan, and Kurland, 1966).

\section{Aetiology of Amyotrophic Lateral Sclerosis and Parkinsonian Dementia}

The aetiology of the sporadic or classical, the familial and presumably hereditary types of ALS, and the Mariana Islands or western Pacific islands form of ALS and PD remains undetected and unknown. Since 1963, coincident with the initiation of long-term studies to elicit the aetiology of kuru, experiments were initiated in an attempt to transmit to an animal or avian host other chronic and subacute progressive degenerative disease of the human central nervous system that includes sporadic and familial cases of ALS with particular emphasis on the Guam foci (Gajdusek and Gibbs, 1964). Isolation of virus for kuru (Gajdusek, Gibbs, and Alpers, 1966), followed closely by the isolation of the virus of Creutzfeldt-Jakob disease (Gibbs, Gajdusek, Asher, Alpers, Beck, Daniel, and Matthews, 1968), unquestionably the most exciting developments in the pathogenesis of neurological diseases in this decade, strengthened our hypothesis that additional chronic subacute progressive degenerative diseases of the central nervous system of man might have infection as their aetiology. This would be particularly true for ALS because of its widespread distribution in sporadic and familial forms and the statistically high number of cases occurring in foci on Guam, the Kii peninsula of Japan (Kimura et al, 1963), and in Kepe, a remote village near the southern coast of western New Guinea (Gajdusek, 1963).

Nathanson, El Dada, and Price (1968) have reviewed the potential role of 'fast' viruses in amyotrophic lateral sclerosis. As cited by them, the suggestion has appeared repeatedly in the literature that there may be a relationship between poliomyelitis and amyotrophic lateral sclerosis. For example, he points out: (1) chronic progressive neurological disease with muscular weakness and atrophy labelled as chronic or subacute poliomyelitis has a clinical picture compatible with ALS; (2) it has been claimed 
that ALS patients have a commoner history of preceding poliomyelitis than expected by chance-an observation that has not been confirmed from analysis of other series of cases or by sero-epidemiological studies (Kurland, 1957, 1965); (3) the possibility that classic acute poliomyelitis with residual dysfunction may simulace ALS in manifesting upper and lower motor neurone dysfunction; and (4) isolation of polio virus from the central nervous system of human cases long after onset of acute diseasealthough we know of no such reports. Thus, though much has been speculatively suggested there is in my mind no convincing evidence of a relationship between polio virus infection and amyotrophic lateral sclerosis.

Inclusion bodies have been reported by Hirano et al (1968) in the brains of some patients dying with amyotrophic lateral sclerosis. In their opinion they are indistinguishable by light microscopy from the neuronal inclusion bodies found in rabies.

Tables II and III summarize in detail our attempts to transmit ALS, ALS-PD, and Parkinson's disease to primates by inoculation of suspensions of tissues from patients in the United States and on Guam. In addition, Table II contains a summary of our attempts to passage ALS serially into monkeys inoculated with a suspension of brain and cord from a rhesus monkey reportedly dying with ALS in the USSR (Zil'ber, Baidokova, Gardashian, Konovalov, Bunina, and Barabadze, 1962, 1963). Specimens have been collected, preserved, and processed in a manner similar to that described in detail for kuru (Gajdusek and Gibbs, 1964). Table II summarizes data on experiments initiated during the years 1963 to 1966 while Table III summarizes the status of experiments initiated during the period 1968-71. As may be noted,

\begin{tabular}{|c|c|c|c|c|c|c|c|c|c|c|c|c|}
\hline \multicolumn{5}{|l|}{$\begin{array}{l}\text { Source of } \\
\text { Inoculum }\end{array}$} & \multicolumn{5}{|c|}{ Number of Primates Inoculated per Species } & \multirow{2}{*}{$\begin{array}{l}\text { Total } \\
\text { Primates }\end{array}$} & \multirow{2}{*}{$\begin{array}{l}\text { Months } \\
\text { on Test }\end{array}$} & \multirow{2}{*}{$\begin{array}{l}\text { Deaths } \\
\text { (Non- } \\
\text { specific) }\end{array}$} \\
\hline Patient & Date & Tissue & Dilution Treatment & Route & $\begin{array}{l}\text { Chim- } \\
\text { panzee }\end{array}$ & $\begin{array}{l}\text { African } \\
\text { Green }\end{array}$ & $\begin{array}{l}\text { Cyno- } \\
\text { molgus }\end{array}$ & Rhesus & Patas & & & \\
\hline \multicolumn{13}{|l|}{$A L S(U S A)$} \\
\hline $\mathbf{M}$ & $8 / 64$ & Blood clot & $10 \%$ homogenized & ic, iv & & & & 1 & & 1 & 39 & 1 \\
\hline $\mathbf{K}, \mathbf{F}, \mathbf{B}$ & $8 / 64$ & $\begin{array}{l}\text { Pooled } \\
\text { blood clot }\end{array}$ & $10 \%$ homogenized & ic, iv & & & & 2 & & 2 & 39 & 2 \\
\hline $\mathbf{F}$ & $10 / 64$ & Brain & $10 \%$ & ic, iv & & & & 3 & & & & \\
\hline & & & & ic, ip & & & & 1 & & & & \\
\hline & & & & ic & & & & 1 & & 5 & 41 & 5 \\
\hline Mo & $10 / 64$ & Whole blood & undiluted sonic vibrated & ic, iv & & & & 2 & & 2 & 46 & 2 \\
\hline $\mathbf{E}$ & $10 / 64$ & Whole blood & undiluted sonic vibrated & ic, iv & & & & 2 & & 2 & 46 & 2 \\
\hline $\mathbf{S}$ & $5 / 65$ & Brain & $1: 5$ & ic, iv & & & & 3 & & 3 & 38 & 3 \\
\hline \multicolumn{13}{|c|}{ Parkinson's Dementia (USA) } \\
\hline $\mathbf{R}$ & $5 / 65$ & Brain & $10^{-5}$ & ic, iv & & & & 2 & & 2 & 38 & 2 \\
\hline \multicolumn{13}{|c|}{ Parkinson's Disease (USA) } \\
\hline $\mathbf{Z}$ & $5 / 65$ & $\begin{array}{l}\text { Brain } \\
\text { Biopsy }\end{array}$ & $1: 2$ & ic, iv & $1(\mathrm{~A} 12)$ & & & 2 & & 3 & 81 & 3 \\
\hline \multicolumn{13}{|c|}{ ALS (Guam in Chamorros) } \\
\hline $\mathrm{Sa}$ & $9 / 63$ & Brain & $10 \%$ & ic, iv & & 4 & 6 & & & 10 & 55 & 10 \\
\hline $\mathrm{Ta}$ & $9 / 63$ & Brain & $10 \%$ & ic, iv & & 2 & 5 & & & 7 & 59 & 7 \\
\hline $\mathbf{N}$ & $9 / 63$ & Brain & $10 \%$ & ic, iv & & 2 & 5 & & & 7 & 49 & 2 \\
\hline D & $7 / 66$ & Brain & $10 \%$ & ic, iv & 1 (A36) & 1 & 1 & 1 & 1 & 5 & 67 & 4 \\
\hline $\mathbf{R e}$ & $11 / 66$ & Brain & $10 \%$ & ic, iv & 1 (A55) & & & & & 1 & 63 & 0 \\
\hline \multicolumn{13}{|c|}{$A L S-P D$ (Guam in Chamorros) } \\
\hline $\mathrm{T}$ & $8 / 63$ & Brain & $10 \%$ & ic & 1 (A3) & 2 & 4 & & & 7 & 100 & 6 \\
\hline & $1 / 64$ & Brain & $10 \%$ & ic & & 1 & 1 & & & 2 & 55 & 2 \\
\hline Do & $9 / 63$ & Brain & $10 \%$ & ic, iv & & 2 & 5 & & & 7 & 60 & 7 \\
\hline A, G, Bo, V & $8 / 64$ & Pooled brain & $10 \%$ & ic, iv & & & & 2 & & 2 & 48 & 2 \\
\hline To & $7 / 66$ & Brain & $10 \%$ & ic, iv & $1(\mathrm{~A} 35)$ & 1 & 1 & 1 & 1 & 5 & 25 & 5 \\
\hline & $11 / 66$ & Brain & $10 \%$ & ic, iv & 1 (A51) & & & & & 1 & 63 & 0 \\
\hline \multicolumn{13}{|c|}{$\begin{array}{l}\text { ALS (experimental) (Rhesus monkey from USSR) } \\
\text { PEAN-N }\end{array}$} \\
\hline 3098 & $8 / 64$ & Brain and & $10 \%$ & ic & & & & 4 & & 4 & 38 & 2 \\
\hline & & spinal cord & $10^{-3}$ & ic & & & & 1 & & 1 & 39 & 1 \\
\hline & & & $10^{-5}$ & ic & & & & 1 & & 1 & 39 & 1 \\
\hline & & & $10 \%$ Seitz EK filter & ic & & & & 1 & & 1 & 39 & 1 \\
\hline & & & $10 \% 220 \mathrm{~nm}$ millipore & ic & & & & 1 & & 1 & 3 & 1 \\
\hline & & & $10 \%$ incubated $^{1}$ & ic & & & & 1 & & 1 & 8 & 1 \\
\hline & & & $10^{-3}$ incubated $^{1}$ & ic & & & & 1 & & 1 & 26 & 1 \\
\hline
\end{tabular}

Table II A summary of attempts to transmit to primates ALS, ALS-PD, Parkinson's disease, and experimental ALS of primates (USSR type)

${ }^{1}$ With pooled human ALS serum two hours in ice bath.

${ }^{2}$ Months on test before death.

${ }^{3}$ Died of intercurrent disease; neuropathological findings not compatible with diagnostic criteria established for the specific disease under study. 


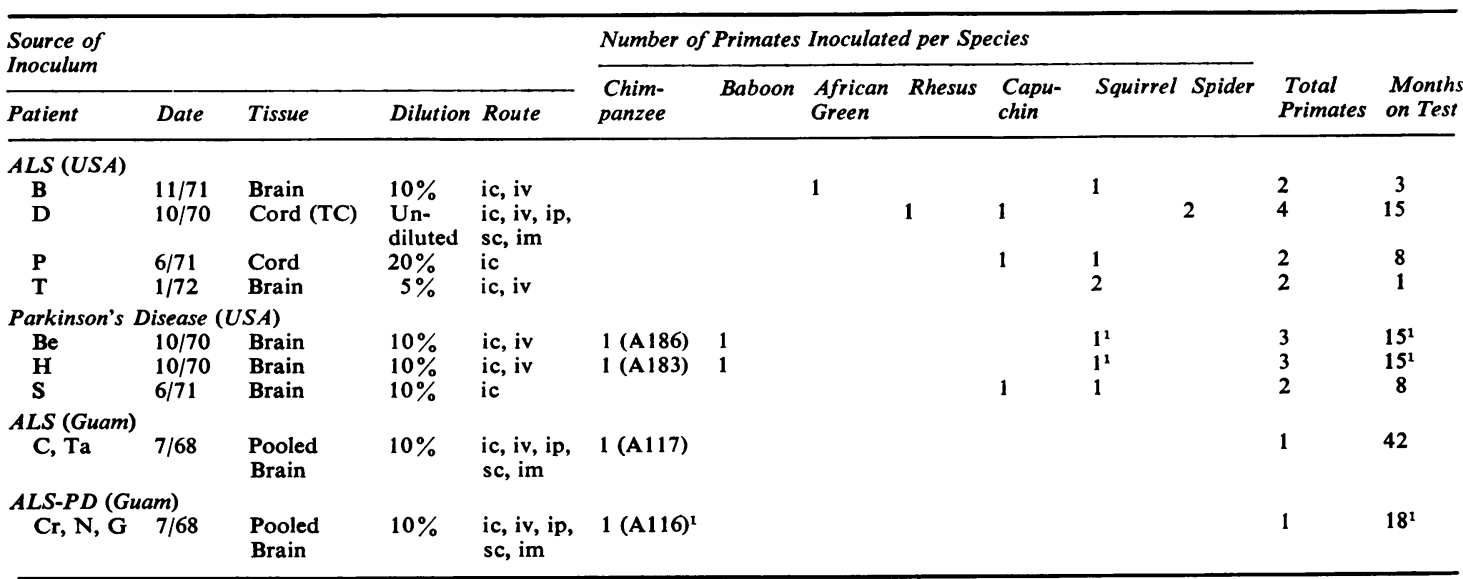

Table III Further attempts to transmit to primates ALS, ALS-PD, and Parkinson's disease

${ }^{1}$ Died of non-specific causes (neuropathological findings not compatible with diagnostic criteria established for the specific disease under study)

chimpanzees and eight species of old and new world monkeys have been observed for periods ranging from only one month to more than 100 months following intracerebral inoculation of brain tissue obtained at surgical biopsy or early necropsy, pooled whole blood, and blood clots from patients with ALS, PD, and amyotrophic lateral sclerosisParkinsonism-dementia. Although 76 of the 104 primates under study have died of intercurrent infections during the more than nine years these studies have been conducted, no illness relatable to the inoculum has appeared amongst them. Over $85 \%$ of the animals listed as dead (64 animals) were killed because of their exposure to an outbreak of tuberculosis in a commercial animal house in which they were housed. Most importantly, the brain, cord, and visceral tissues from each of the 76 animals that have died during the course of these experiments have been studied histologically by Mrs Beck at the Institute of Psychiatry, London, Professor Osetowska in Warsaw, Dr Byron Kakulas in Perth, and Dr Kenneth Earle and his colleagues at the Armed Forces Institute of Pathology in Washington, DC. In no instance have gross or microscopic lesıons been observed that would suggest pathology of ALS or PD in monkeys that had been on test for from a few months to many months after inoculation with optimally obtained specimens. All specimens listed in Tables II and III were inoculated into small laboratory animals and avian hosts which were then held for a minimum of one year and frequently for as long as three years without exhibiting clinical or histological signs of neurological disease.

Tissues from 16 of the patients have been extensively studied as explants in vitro and trypsinized cultures by Miss Nancy Rogers, a member of our research team. Tables IV and V summarize her current findings on these 16 patients and list the maximum time in days that specific tissue from a given patient has been maintained and studied as viable cells in vitro. In every instance supernatant fluids, cell debris, and disrupted viable cells have been blind passaged into a number of primary and stable cell lines including human embryo kidney (HEK), human brain (Flow 3000), WI-38, BS-C-1, Vero, MA184, and BHK-21. The early isolation of strains of reovirus were not relatable to the donor patient and we are currently of the opinion that they were the result of laboratory cross contamination, since at that time reovirus types 1,2 , and 3 were under study in our laboratory. However, utilization of the technique of long-term maintenance of explanted tissues from kuru-affected chimpanzees and from Creutzfeldt-Jakob disease-affected human subjects and chimpanzees have been used successfully to demonstrate the persistence of both viruses in vitro (Gajdusek, Gibbs, Rogers, Basnight, and Hooks, 1972). Kuru persisted in chimpanzee brain cells growing in vitro at $37^{\circ} \mathrm{C}$ for 70 days and the virus of Creutzfeldt-Jakob disease persisted in explanted cultures oi human brain cells growing in vitro at $37^{\circ} \mathrm{C}$ for 255 days. Further, the use of this in-vitro technique has been responsible for the isolation of more than 200 virus strains from kuruaffected and Creutzfeldt-Jakob disease-affected chimpanzees and new-world monkeys as well as from uninoculated control animals that have died with intercurrent infections. These strains have included new adenoviruses, new simian foamy viruses which have reverse transcriptase, an apparently new strain of simian herpes virus, and reoviruses 1 and 2 . Similarly, the same basic technique has successfully 


\begin{tabular}{|c|c|c|c|c|c|c|c|c|c|c|c|c|}
\hline \multirow[t]{3}{*}{ Patient } & \multirow[t]{3}{*}{$T y p e^{2}$} & \multirow[t]{3}{*}{ Date } & \multicolumn{10}{|c|}{ Maximum Number of Days Primary and Subcultures Survived } \\
\hline & & & \multicolumn{7}{|l|}{ Brain } & \multicolumn{3}{|l|}{ Cord } \\
\hline & & & $\begin{array}{l}\text { Cere- } \\
\text { bellum }\end{array}$ & Frontal & Temporal & Parietal & Occipital & $\begin{array}{l}\text { Motor } \\
\text { Cortex }\end{array}$ & $\begin{array}{l}\text { Sensory } \\
\text { Cortex }\end{array}$ & Lumbar & Cervical & Thoracic \\
\hline \multirow{15}{*}{$\begin{array}{l}65-116 \\
66-8 \\
66-19 \\
66-66 \\
68-32 \\
70-3 \\
70-261^{1} \\
70-262^{1} \\
70-263^{1} \\
71-161 \\
71-162 \\
71-266 \\
71-281^{1} \\
71-283 \\
71-293^{1} \\
71-490\end{array}$} & $\mathbf{P M}$ & $11 / 65$ & & $246(t)^{3}$ & $288(+)^{3}$ & & $288(+)^{3}$ & & & & & \\
\hline & $\begin{array}{l}\text { PM } \\
\text { PM }\end{array}$ & $\begin{array}{l}1 / 66 \\
2 / 66\end{array}$ & & $183(+)^{5}$ & & N.G. & & N.G. & $255(+)^{4}$ & & N.G. & N.G. \\
\hline & PM & $\begin{array}{l}2 / 06 \\
11 / 66\end{array}$ & N.G. & $183(+)^{\circ}$ & & 587 & & & & 90 & 189 & 237 \\
\hline & BX & $5 / 68$ & & 731 & & & & & & & & \\
\hline & PM & $1 / 70$ & 41 & & & & & & & N.G. & N.G. & N.G. \\
\hline & PM & $2 / 70$ & N.G. & N.G. & N.G. & N.G. & N.G. & & & & & \\
\hline & PM & $8 / 70$ & 264 & 259 & & 223 & & & & & & \\
\hline & $\mathbf{P M}$ & $2 / 70$ & 266 & 208 & 200 & 196 & 294 & & & & & \\
\hline & PM & $7 / 71$ & \multicolumn{10}{|c|}{ Multiple areas of brain pooled $P / 1133 ; P / 260$} \\
\hline & PM & $7 / 71$ & \multicolumn{10}{|c|}{ No growth in brain pool at 89 days } \\
\hline & BX & $8 / 71$ & \multicolumn{10}{|c|}{ P/1 106} \\
\hline & BX & $8 / 71$ & \multicolumn{10}{|c|}{ P/2 67} \\
\hline & PM & $8 / 71$ & \multirow{2}{*}{\multicolumn{10}{|c|}{$\begin{array}{l}\text { Brain and cord mixed P/1 180; P/2 } 67 \\
\text { Brain pool }=\text { no growth at } 87 \text { days }\end{array}$}} \\
\hline & PM & $8 / 71$ & & & & & & & & & & \\
\hline & $\mathbf{P M}$ & $9 / 71$ & \multicolumn{7}{|c|}{$\mathbf{P} / 147$} & $P / 147$ & 47 & 47 \\
\hline
\end{tabular}

Table IV Summary of in-vitro explant cultures of central nervous system tissues from 16 patients with amyotrophic lateral scleresis and amyotrophic lateral sclerosis-Parkinsonism-dementia complex

${ }^{1}$ Guam cases.

:PM $=$ postmortem; $\mathbf{B X}=$ biopsy.

N.G. = no growth.

$P / 1 \ldots 2$ indicates serial in vitro subculture level of cells.

${ }^{3}$ Reo-virus-like isolate; fluids haemagglutinated type ' $O$ ' human rbc's.

'Culture fluids haemagglutinated type ' $O$ ' human rbc's haemagglutination inhibited by antibody in horse sera to Reo-virus types 1,2 , 3 .

${ }^{5}$ Reo-virus type 1 isolate.

\begin{tabular}{|c|c|c|c|c|c|c|}
\hline \multirow[t]{3}{*}{ Patient } & \multirow[t]{3}{*}{ Type ${ }^{2}$} & \multirow[t]{3}{*}{ Date } & \multicolumn{4}{|c|}{$\begin{array}{l}\text { Maximum Number of Days Primary and } \\
\text { Subcultures Survived }\end{array}$} \\
\hline & & & \multicolumn{3}{|l|}{ Viscera } & \multirow[t]{2}{*}{ Muscle } \\
\hline & & & Liver $^{3}$ & Kidney & Spleen & \\
\hline $\begin{array}{l}65-116 \\
66-8\end{array}$ & $\begin{array}{l}\text { PM } \\
\text { PM }\end{array}$ & $\begin{array}{l}11 / 65 \\
1 / 66\end{array}$ & $\begin{array}{l}246(+) \\
\text { N.G. }\end{array}$ & 549 & 1150 & \\
\hline $69-165$ & BX & $\begin{array}{l}1 / 00 \\
7 / 69\end{array}$ & & 349 & & $\mathrm{P} / 2114$ \\
\hline $70-261^{1}$ & $\mathbf{P M}$ & $2 / 70$ & & 210 & 210 & \\
\hline $70-262^{1}$ & PM & $8 / 70$ & & 243 & 223 & \\
\hline $71-161$ & $\mathbf{P M}$ & $7 / 71$ & & & & $\begin{array}{ll}\mathrm{P} / 1 & 140 \\
\mathrm{P} / 2 & 60\end{array}$ \\
\hline $71 / 162$ & $\mathbf{P M}$ & $7 / 71$ & & & & 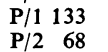 \\
\hline $71 / 165$ & BX & $7 / 71$ & & & & $\begin{array}{lr}P / 1 & 133 \\
P / 2 & 61\end{array}$ \\
\hline $71 / 263$ & BX & $7 / 71$ & & & & 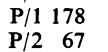 \\
\hline $71 / 264$ & BX & $8 / 71$ & & & & 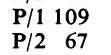 \\
\hline $71 / 265$ & BX & $8 / 71$ & & & & $\begin{array}{ll}P / 1 & 176 \\
P / 2 & 67\end{array}$ \\
\hline $71 / 266$ & BX & $8 / 71$ & & & & 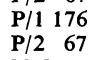 \\
\hline $\begin{array}{l}71-283 \\
71-490\end{array}$ & $\begin{array}{l}\mathbf{P M} \\
\mathbf{P M}\end{array}$ & $\begin{array}{l}8 / 71 \\
9 / 71\end{array}$ & & $P / 147$ & & N.G. \\
\hline
\end{tabular}

Table V Summary of in-vitro explant cultures of visceral and muscle tissues from 14 patients with amyotrophic lateral sclerosis and amyotrophic lateral sclerosis-Parkinsonism-dementia complex

${ }^{1}$ Guam cases.

2PM $=$ postmortem; $\mathbf{B X}=$ biopsy

N.G. = no growth

$\mathbf{P} / 1 \ldots 2$ indicates serial in vitro subculture level of cells.

${ }^{3}$ Culture fluids haemagglutinated type ' $O$ ' human rbcs; haemagglutination inhibited by antibody in horse sera to reovirus types $1,2,3$. been employed to isolate the latent $\mathrm{SV}_{40}$-like papova virus from patients with progressive multifocal leucoencephalopathy (Padgett, Walker, ZuRhein, Eckroade, and Dessel, 1972), the measles virus of subacute sclerosing panencephalitis (Baublis and Payne, 1968), and to demonstrate persistence and replication of scrapie in explant cultures of scrapieinfected mouse brain (Gustafson and Kanitz, 1965; Haig and Clarke, 1971). It is anticipated that longmaintained explant cultures of human tissues will yield additional latent and persistent virus that may or may not be the causative agent of the diseases under study. A word of caution, however; the mere detection of virus-like structures by electron microscopy in brain or residual tissue without further evidence of its relationship to the patient and the disease under study does not warrant a conclusion of an aetiological relationship.

Transmission of Amyotrophic Lateral Sclerosis in the USSR

Finally, no discussion on the aetiology of ALS would be complete without a consideration of the work on this disease in the USSR. In 1963 Zil'ber and his colleagues reported the successful transmission of ALS to rhesus monkeys inoculated with saline extracts of the medulla and spinal cords of patients who had died of the sporadic type of the disease. A 
monkey inoculated in 1956 was observed one year later to have developed amyotrophy of the muscles of the left forearm and hand, exaggeration of stretch reflexes in the hind limbs, and loss of weight. These signs became more manifest during the ensuing 18 months (two and a half years after inoculation), at which time the animal was sacrificed and a homogenate of its spinal cord was injected into two monkeys. Both second-passage monkeys were reported to have developed a motor neurone disease.

Tissues from one of the second-passage animals, sacrificed during clinical disease four years and 10 months after inoculation (that is almost two years after the onset of disease), were brought to our laboratories in 1962 by the late Dr Zil'ber and together we inoculated 10 monkeys intracerebrally and peripherally with $20 \%$ suspensions of brain and cord as well as with brain suspensions that had been filtered or mixed with serum from ALS patients in an attempt to demonstrate an aetiological relationship through neutralizing antibodies. Other animals were inoculated with serial 10 -fold dilutions of the Zil'ber monkey material in an attempt to demonstrate infectivity titres of the reported virus (see Table II). Three animals died from three to eight months after inoculation, and their central nervous system tissues were normal on gross and histological examination. Four additional animals were killed 30 months after inoculation and again histological lesions in the brain were not observed. Four animals were killed 47 months after inoculation without evidence of lesions.

In contrast to our studies is the recent report of Gardashian and her coworkers, who are continuing the work of Zil'ber.Table VI, taken from the paper by Gardashian, Khondkarian, Bunina, Popova, and Katkin (1970), summarizes the results of their most recent transmission experiments utilizing tissues from 'ALS patients with different forms of

\begin{tabular}{|c|c|c|c|c|c|}
\hline \multirow[t]{2}{*}{ Passage } & \multicolumn{2}{|c|}{ Monkeys Inoculated } & \multicolumn{2}{|c|}{ Monkeys Becoming III } & \multirow[b]{2}{*}{$\begin{array}{l}\text { Total } \\
\text { Monkeys }\end{array}$} \\
\hline & $\begin{array}{l}\text { Total No. } \\
\text { Monkeys }\end{array}$ & $\begin{array}{l}\text { No. Living } \\
\text { One Year } \\
\text { after } \\
\text { Inoculation }\end{array}$ & $\begin{array}{l}\text { Mild } \\
\text { Neuro- } \\
\text { logical } \\
\text { Signs }\end{array}$ & $\begin{array}{l}\text { With } \\
\text { Motor } \\
\text { Dis- } \\
\text { turbances }\end{array}$ & \\
\hline Ist & 14 & 12 & 2 & 3 & $5 / 12$ \\
\hline 2nd & 15 & 14 & 5 & 4 & $9 / 14$ \\
\hline 3 rd & 7 & 3 & 3 & - & $3 / 3$ \\
\hline Total & 36 & 29 & 10 & 7 & $17 / 29$ \\
\hline
\end{tabular}

Table VI Results of infection of monkeys with material from ALS patients in USSR ${ }^{1}$

'Gardash'yan, A. M., Khondkarian, O. A., Bunina, T. L., Popova, L. M., Katkin, S. G. (1970). Experimental data on the study of the etiology of amyotrophic lateral sclerosis. Vestnik Acad. Med. Sci., USSR (9): 80-83.

¿Denominator: total monkeys, numerator: number ill. illness (bulbar, lumbosacral and cervico-thoracic)' as well as control animals inoculated with tissues of the central nervous system from patients dying of accidental causes. They considered only animals which lived over one year after inoculation. 'Monkeys becoming ill' were divided into those with mild neurological signs (atrophy of muscles, of extremities with increased tendon reflexes and diminished strength with motor disturbances) and those with marked or severe motor disturbances (characterized by increasingly dense paresis of the extremities, marked atrophy of muscles combined with increased reflexes, adductor and contralateral responses with knee jerks and clonus of feet).

On primary passage material from eight patients with ALS was used to inoculate 14 monkeys. Of these 12 lived for at least one year after inoculation. Inoculum consisted of supernatant fluids of $1: 3$ of $1: 5(\mathrm{w} / \mathrm{v})$ brain and cord suspensions spun at 1500 to $3000 \mathrm{rpm}$. Signs of neurological disease are reported to have developed in five of 12 animals two to four years after inoculation. Three animals had severe motor disturbances and two had mild neurological signs. Three of the five monkeys were sacrificed and brain tissue was used to infect 14 animals on second passage. As shown, nine of the 14 became ill, five with mild signs and four with severe motor impairment. Incubation periods ranged from $20 \frac{1}{2}$ months to 48 months. Two monkeys of this passage, one with severe disease and the other with mild disease, recovered completely following clinical disease of two years' duration.

Finally, on third passage three of three monkeys developed mild neurological signs with incubation periods ranging from two and a half to three and a half years after inoculation with supernatant fluid of $10 \%$ brain following centrifugation at $2000 \mathrm{rpm}$, sediment of brain following centrifugation at 50000 $\mathrm{rpm}$, and undiluted cerebrospinal fluid from 'experimentally affected animals'. Of the three, two died of 'intercurrent' infections and the remaining one animal recovered after two years of clinical disease.

Histological lesions were observed only in the brain and spinal cord of affected monkeys and consisted of loss of motor cells of the anterior horn in the spinal cord and pyramidal cell loss in the third and fourth layers of the motor cortex. There was moderate demyelination in the white matter of the spinal cord accompanied by glial and vascularmesenchymal reaction. No mention is made of histopathological findings in monkeys that apparently recovered following two to three years of severe clinical disease.

Our failure to confirm the transmission of ALS from man to primates or even to transmit disease to rhesus monkeys by their inoculation with brain and 
spinal cord from affected monkeys in the USSR draws attention to the reports by Brody, Hadlow, Hotchin, Johnson, Koprowski, and Kurland (1965) that neither clinical nor pathological localization of the disease in monkeys in the USSR has been definitely established. Further, Hirano (1965) reported that he was unable to detect microscopic changes resembling ALS in the brain and spinal cord of monkeys which developed the ALS syndrome following inoculation by Zil'ber. Thus, it has not been established that a transmissible agent causing motor neurone disease in primates is the aetiological agent of motor neurone disease in man.

In summary, although a good case for infection as the aetiology of ALS and ALS-PD can be proposed on an epidemiological basis, no direct nor convincing evidence to support this hypothesis has been obtained during the past eight to 10 years of our work. We look more optimistically towards the transmission of sporadic and familial Alzheimer and Pick disease. Perhaps with the continued application of newer techniques in tissue and cell cultures, the activation of viral genome by treatment of cells with IUDR and BUDR and other techniques to unmask latent but persistent viruses we may yet be successful in determining the aetiology of ALS - a major problem in neurological diseases.

\section{References}

Baublis, J. V., and Payne, F. E. (1968). Measles antigen and syncytium formation in brain cell cultures from subacute sclerosing panencephalit is (SSPE). Proc. Soc. exp. Biol. (N.Y.), 129, 593-597.

Brody, J. A. (1971). Epidemiology of amyotrophic lateral sclerosis. and Parkinsonism-dementia of Guam: recent observations. In International Congress on Muscle Diseases, Perth, Western Australia, 1971. (International Congress Series, no. 337). Excerpta Medica Foundation, Amsterdam.

Brody, J. A., and Chen, K. (1968). Changing epidemiological patterns of amyotrophic lateral sclerosis and Parkinsonism-dementia on Guam. In Motor Neuron Diseases: Research on Amyotrophic Lateral Sclerosis and Related Disorders (Contemporary Neurology Symposia, Vol. II), edited by F. H. Norris, Jr., and L. T. Kurland, pp. 61-79. Grune and Stratton, New York and Londen.

Brody, J. A., Hirano, A., and Scott, R. M. (1971). Recent neuropathologic observations in amyotrophic lateral sclerosis and Parkinsonism-dementia of Guam. Neurology (Minneap.), 21, 528-536.

Brody, J. A., Hadlow, W. J., Hotchin, J., Johnson, R. T., Koprowski, H., and Kurland, L. T. (1965). Soviet search for viruses that cause chronic neurologic diseases in the U.S.S.R. Science, 147, 1114-1116.

Charcot, J. M. (1874). De la sclı̀rose latérale amyotrophique. Progr. med. (Paris), 2, 325-327, 341-342, 452-455.

Elizan, T. S., Hirano, A., Abrams, B. M., Need, R. L., Van Nuis, C., and Kurland, L. T. (1966). Amyotrophic lateral sclerosis and Parkinsonism-dementia complex of Guam: neurological reevaluation. Arch. Neurol., 14, 356-368.

Engel, W. K., Kurland, L. T., and Klatzo, I. (1959). An inherited disease similar to amyotrophic lateral sclerosis with a pattern of posterior column involvement. An intermediate form? Brain, 82, 203-220.

Gajdusek, D. C. (1963). Motor neuron disease in natives of New Guinea. New Engl. J. Med., 268, 474-476.

Gajdusek, D. C., and Gibbs, C. J., Jr. (1964). Attempts to demonstrate a transmissible agent in kuru, amyotrophic lateral sclerosis and other sub-acute and chronic nervous system degenerations of man. Nature (Lond.), 204, 257-259.

Gajdusek, D. C., Gibbs, C. J., Jr., and Alpers, M. (1966). Experimental transmission of a kuru-like syndrome to chimpanzees. Nature (Lond.), 209, 794-796.

Gajdusek, D. C., Gibbs, C. J., Jr., Rogers, N. G., Basnight, M., and Hooks, J. (1972). Persistence of viruses of kuru and CreutzfeldtJakob disease in tissue cultures of brain cells. Nature (Lond.). 235, 104-105

Gardashian, A. M., Khondkarian, O. A., Bunina, T. L., Popova, L. M., and Katkin, S. G. (1970). Experimental data on the study of the etiology of amyotrophic lateral sclerosis. Vestn. Akad. med. Sci., 9 (10), 80-83.

Gibbs, C. J., Jr. (1967). Search for infectious etiology in chronic and subacute degenerative diseases of the central nervous system. Curr. Top. Microbio!. Immunol., 40, 44-58.

Gibbs, C. J., Jr., and Gajdusek, D. C. (1968). Kuru-a prototype subacute infectious disease of the nervous system as a model for the study of amyotrophic lateral sclerosis. In Motor Neuron Diseases: Research on Amyotrophic Lateral Sclerosis and Related Disorders (Contemporary Neurology Symposia, Vol. II), edited by F. H. Norris, Jr., and L. T. Kurland, pp. 269-279. Grune and Stratton, New York and London.

Gibbs, C. J., Jr., Gajdusek, D. C., Asher, D. M., Alpers, M. P., Beck, E., Daniel, P. M., and Matthews, W. B. (1968). CreutzfeldtJakob disease (spongiform encephalopathy): transmission to the chimpanzee. Science, 161, 388-389.

Goldblatt, D. (1968). Motor neuron disease: historical introduction. In Motor Neuron Diseases: Reserach on Amyotrophic Lateral Sclerosis and Related Disorders (Contemporary Neurology Symposia, Vol. II), edited by F. H. Norris, Jr., and L. T Kurland, pp. 3-11. Grune and Stratton, New York, and London.

Gustafson, D. B., and Kanitz, C. L. (1965). Evidence of the presence of scrapie in cell cultures of the brain. In Slow, Latent and Temperate Virus Infections, edited by D. C. Gajdusek, C. J. Gibbs, Jr., and M. Alpers, pp. 221-236. (NINDB Monographs, No. 2. National Institute of Neurological Diseases and Blindness, Washington, D.C.

Haig, D. A., and Clarke, M. C. (1971). Multiplication of the scrapie agent. Nature (Lond.), 234, 106-107.

Hirano, A. (1965). Pathology of amyotrophic lateral sclerosis. In Slow, Latent and Temperate Virus Infections, edited by D. C. Gajdusek C. J. Gibbs, Jr., and M. Alpers, pp. 23-37. (NINDB Monographs, No. 2. National Institute of Neurological Diseases and Blindness, Washington, D.C.

Hirano, A. (1966). Neuropathology of amyotrophic lateral sclerosis and Parkinsonism-dementia complex on Guam. In Proceedings of the Fifth International Congress of Neuropathology, Zurich, 1965 (Excerpta Medica International Congress Series, No. 100), pp. 190-194. Excerpta Medica Foundation, Amsterdam.

Hirano, A., Kurland, L. T., Krooth, R. S., and Lessell, S. (1961a). Parkinsonism-dementia complex, an endemic disease on the island of Guam. I. Clinical features. Brain, 84, 642-661.

Hirano, A., Malamud, N., Elizan, T. S., and Kurland, L. T. (1966). Amyotrophic lateral sclerosis and Parkinsonism-dementia complex on Guam. Further pathologic studies. Arch. Neurol., 15, 35-51.

Hirano, A., Malamud, N., and Kurland, L. T. (1961b). Parkinsonismdementia complex, an endemic disease on the island of Guam. II. Pathological features. Brain, 84, 662-679.

Hirano, A., Malamud, N., Kurland, L. T., and Zimmerman, H. M. (1968). A review of the pathologic findings in amyotrophic lateral sclerosis. In Motor Neuron Diseases: Research on Amyotrophic Lateral Sclerosis and Related Disorders (Contemporary Neurology Symposia, Vol. II), edited by F. H. Norris, Jr., and L. T. Kurland, pp. 51-60. Grune and Stratton, New York and London.

Hirano, A., and Zimmerman, H. M. (1962). Alzheimer's neurofibrillary changes: a topographic study. Arch. Neurol., 7, 227-242.

Kimura, K., et al (1963). Epidemiological and geomedical studies on amyotrophic lateral sclerosis. Dis. nerv. Syst., 24, 155-159.

Kurland, L. T. (1957). Epidemiologic investigations of amyotrophic lateral sclerosis. III. A genetic interpretation of incidence and geographic distribution. Froc. Mayo Clin., 32, 449-462.

Kurland, L. T. (1965). Amyotrophic lateral sclerosis. In Slow, Latent and Temperate Virus Infections, edited by D. C. Gajdusek, C., M. J. Gibbs, Jr., and Alpers, pp. 13-22. (NINDB Monographs 
No. 2, PHS Publications, No. 1378). National Institute of Neurological Diseases and Blindness, Washington, D.C.

Kurland, L. T., Choi, N. W., and Sayre, G. P. (1968). Implications of incidence and geographic patterns on the classification of amyotrophic lateral sclerosis. In Motor Neuron Diseases: Research on Amyotrophic Lateral Sclerosis and Related Disorders (Contemporary Neurology Symposia, Vol. II), edited by F. H. Norris, Jr., and L. T. Kurland, pp. 28-50. Grune and Stratton, New York and London.

Mulder, D. W., and Espinosa, R. E. (1968). Amyotrophic lateral sclerosis: comparison of the clinical syndrom in Guam and the United States. In Motor Neuron Diseases: Research on Amyotrophic Lateral Sclerosis and Related Disorders (Contemporary Neurology Symposia, Vol. II), edited by F. H. Norris, Jr., and L. T. Kurland, pp. 12-19. Grune and Stratton, New York and London.

Nathanson, N., El Dadah, A. H., and Price, W. H. (1968). Chronic and late central nervous system disease produced by fast viruses. In Motor Neuron Diseases: Research on Amyotrophic
Lateral Sclerosis and Related Disorders (Contemporary Neurology Symposia, Vol. II), edited by F. H. Norris, Jr., and L. T. Kurland, pp. 254-263. Grune and Stratton, New York and London.

Padgett, B. L., Walker, D. L., ZuRhein, G. M., Eckroade. R. J., and Dessel, B. H. (1971). Cultivation of papova-like virus from human brain with progressive multifocal leucoencephalopathy. Lancet, 1, 1257-1260.

Yase, Y., Matsumoto, N., Yoskimasu, F., Handa, Y., and Kumamoto, T. (1968). Motor neuron disease in the Kii Peninsula, Japan. Proc. Aust. Ass. Neurol., 5, 335-339.

Zil'ber, L. A., Baidakova, Z. L., Gardashian, A. M.,Konovalov, N. V. Bunina, T. L., and Barabadze, E. M. (1962). Possible viral etiology of a myotrophic lateral sclerosis. Vop. Virusol., 5, 520-528.

Zil'ber, L. A., Baidakova, Z. L., Gardashian, A. N., Konovalov, N. V., Bunina, T. L., and Barabadze, E. M. (1963). Study of the etiology of amyotrophic lateral sclerosis. Bull. Wld Hlth Org., 29, 449-456. 